\title{
How Democracy Backslides: Tracing the Pathway in Six Countries
}

\author{
Ali Riaz \\ Distinguished Professor of Political Science \\ Illinois State University, USA \\ Email: ariaz@ilstu.edu \\ Md. Sohel Rana \\ Graduate Student in Politics \& Government \\ Illinois State University, USA \\ Email: $\underline{\text { mrana1@ilstu.edu }}$
}

Prepared for the Panel "Division 44: Democracy and Autocracy" at the Virtual Annual Meeting of the American Political Science Association (APSA), San Francisco, California, USA, held on September 10-13, 2020. 


\begin{abstract}
The state of global democracy has been witnessing a consistent trend called 'democratic backsliding'. Several studies have explained 'why democracy backslides', nevertheless, attention towards 'how democracy backslides' remains less explored. The current paper meets this gap and examines the processes of democratic backsliding in six countries, namely Bangladesh, Bolivia, Mali, Turkey, Ukraine, and Zambia. We make three interrelated arguments. First, we argue that there are specific milestones in the process of democratic backsliding which accentuates the processes and provides legitimate cover to the actions of the incumbent. Second, as opposed to Levitsky \& Ziblatt (2018)'s three stage model of the backsliding - attacking referees, targeting opponents, and changing the rules of the game, we show that a pattern of changes in the constitution, in other words, changing the rules of the game, is the first step. Third, media manipulation is the second target in the backsliding processes. The paper's contributions are twofold. First, the institutional pathways and the trajectories of democratic backsliding can be traced, thus helping us to identify the potential vulnerable cases. Second, debilitating changes continue to occur as backsliding processes precludes democracies returning to their original positions even when some improvements are made.
\end{abstract}




\section{Introduction}

For the past two decades, the world has been experiencing a democratic reversal trend, widely known as 'democratic backsliding'. Nancy Bermeo (2016) defined 'democratic backsliding' as "the state-led debilitation or elimination of any of the political institutions that sustain an existing democracy" (Bermeo 2016, 5). A global trend of this backsliding has become increasingly evident since 2010. According to The Freedom House, the number of countries declined in democracy has significantly increased from 49 in 2010 to 64 in 2019 (Freedom House 2020, 2). Thus, an erosion to the global share of democracy is manifested. The Varieties of Democracy (V-Dem) 2020 Democracy Report shows that the global percentage of number of democratic countries has declined from 55 percent in 2010 to 48 percent in 2019 (V-Dem 2020, 9). The trend is palpable in the consolidated and new democracies alike, with the latter being more prone to the backsliding (Foa \& Mounk 2016). This global phenomenon raises two significant questions - 'why democracy backslides' and 'how democracy backslides'. While majority of literature has paid much attention on why democracy backslides, in other words, what factors lead to democratic backsliding (Cooley 2015; Fish et al., 2018; Gandhi 2018; Andersen 2019; Lührmann \& Lindberg, 2019), very few studies have explained the question of how democracy backslides, or the process of democratic backsliding (Bermeo 2016; Levitsky \& Lipzatt, 2018). This paper intends to address this gap by investigating the democratic reversal processes that have been followed by six backsliding states.

We offer three interrelated arguments. First, we argue that there are specific milestones in the process of democratic backsliding which accentuates the processes and provides legitimate cover to the actions of the incumbent. We have identified these specific watershed moments drawing on the political history of the selected cases. Second, we interrogate the Levitsky \& Ziblatt (2018)'s three stage model of democratic backsliding - attacking referees, targeting opponents, and changing the rules of the game. Our analysis shows that a pattern of changes in the constitution, or changing the rules of the game, is the first step. Major changes in the constitutions of all these cases have been made mainly on four areas - rule of law, judiciary and legislative, election and civil liberties, and freedom of expression and association. The third finding of the paper is that media become the second casualty of the backsliding processes.

These arguments are drawn through an inductive strategy by closely studying six completely different cases, namely, Bangladesh, Bolivia, Mali, Turkey, Ukraine, and Zambia. The case selection is based on two considerations. First, these cases were featured consistently in the annual reports of the Freedom House and the V-Dem for the 2010-2020 period as democratic backsliding cases. Second, these six countries represent five geographic regions e.g. South Asia, South America, Middle East, Eastern Europe, and Africa and bear dissimilar historical, cultural, political, and demographic characteristics. We aim to explore a similar pattern in the backsliding processes of these dissimilar case studies.

We have used both primary and secondary data, which are derived from two sources. First, we have collected quantitative data for democracy scores of these cases from the Freedom House democracy reports for the 2007-2019 period, which help us to identify the tipping points of democracy in the respective countries. The tipping points lead us to explore specific milestones 
which, in fact, engendered the downward spiral in these cases. Second, we have used findings from available qualitative studies e.g. books, journal accounts, institutional reports, media analyses, and newspaper articles to examine whether such trend is uniform across different regions. Using both quantitative and qualitative findings and applying them into the Levitsky \& Ziblatt framework, we have not only found a uniform pattern in democratic backsliding processes but also identified first and second target of backsliding states.

This paper's contributions are two-fold. First, the institutional pathways and the trajectories of democratic backsliding can be traced, thus helping us to identify the potential vulnerable cases. Second, debilitating changes continue to occur as backsliding processes precludes democracies returning to their original positions even when some improvements are made. We explain these arguments in three parts. We first elaborate existing theoretical insights on democratic backsliding and put forward our rationale for a revision of the Levitsky \& Ziblatt framework. We then explain the trajectories of democratic backsliding processes in the six selected cases while discussing the relevance of the theoretical framework. The final section of this article provides conclusions and implications of the research.

\section{Arguments on 'How Democracy Backslides'}

About the process of democratic backsliding, the seminal works of Nancy Bermeo (2016) and Levitsky and Ziblatt (2018) are most prominent and widely studied. In the piece 'On Democratic Backsliding', Bermeo (2016) argues that the current trends in de-democratization follow three ways - promissory coups, executive aggrandizement, and strategic manipulation of election (813). Promissory coups suggest the ouster of an elected government as a defense of democratic legality and making a public promise to hold elections and restore democracy as soon as possible. Executive aggrandizement occurs when elected executives check the power of the opposition forces to by undertaking a series of institutional changes so that they cannot challenge the executives' preferences. Strategic manipulation of election takes place by restricting media access, using government funds for incumbent campaigns, keeping opposition candidates off the ballot, hampering voter registration, packing electoral commissions, and harassing opponents.

Although Bermeo's piece offers empirical evidence of these tendencies among backsliders and help us to identify the nature of backsliders, it offers no specific process of each of these strategies and how each process unfolds. Her analysis does not provide any specific guidelines about which political institutions are configured first by the backsliders and which one last, when is the process starts and when it ends. Without these points, a generalized process for democratic backsliding cannot be understood.

On the other hand, in the seminal book, 'How Democracies Die?', Levitsky \& Ziblatt (2018) argued that democratic erosion begins in a slow manner which may be imperceptible at first as elections continue to be held and opposition parties and independent newspapers remain active (77). From their argument that "the erosion of democracy often takes place piecemeal, often in baby steps", a three-steps model can be generated. According to them, in the first step, the incumbent targets the referees which are essential to protecting the neutrality of the state and the 
rights of citizens (Levitsky \& Ziblatt, 2018, 78-81). These referees include the judicial system, law enforcement bodies, intelligence, tax, and regulatory agencies. This step aims to ensure the loyalty of these institutions to shield the government from investigation and criminal prosecutions and serve as a powerful weapon for protecting the allies and punishing the opponents. To capture these referees or institutions, the incumbent may use tactics such as blackmail, bribery, replacement of civil servants with loyalists, impeachment, court packing, and creation of new institutions.

In the second step, incumbents target the opponents of the government such as opposition politicians, business leaders, major media outlets, intellectuals, and cultural figures (Levitsky \& Ziblatt, 2018, 81-87). Although authoritarian rulers do not completely wipe out the opponents, they silence them by bribing, bullying, co-opting, offering positions and financial concessions, and using legal means to undermine them. This step aims to weaken and demoralize of the opponents as well as dissuade criticisms of the government. It is important to note that the capturing the referees' step is highly important to make the second step successful as it allows governments to legally repress the opponents.

In the third step, incumbents change the rules of the game by reforming constitution and legislative bodies and electoral systems to consolidate power (Levitsky \& Ziblatt, 2018, 87-88). According to Levitsky and Ziblatt, although these reforms are carried out under the guise of public good, they ultimately allow autocrats to lock in advantages for years and decades. Autocrats gerrymander, alter electoral rules, and configure legislature to ensure continued dominance of the ruling party. In this stage, electoral systems are shaped in such a manner that it delivers victory to the incumbent, even without any apparent electoral fraud (Levitsky \& Ziblatt, 2018, 87-92). It is because of this, Levitsky and Ziblatt noted that, "one of the great ironies of how democracies die is that the very defense of democracy is often used as a pretext for its subversion" (92).

Combining these steps, a three-steps model can be developed (Figure 1), which can be used as an effective analytical tool to examine the process of democratic backsliding. It helps us to identify a step-by-step action of backsliders and how each step interacts with each other throughout the process of democratic erosion.

Figure 1: Three-Steps Model of Backsliding

\section{The Process of Democratic Backsliding}

\begin{tabular}{|l|l|l|}
\hline \multicolumn{1}{|c|}{ Step 1 } & \multicolumn{1}{c|}{ Step 2 } & \multicolumn{1}{c|}{ Step 3 } \\
\hline $\begin{array}{l}\text { Target the Referees of } \\
\text { the State: }\end{array}$ & $\begin{array}{l}\text { Target the Opponents } \\
\text { of the Government: }\end{array}$ & $\begin{array}{l}\text { Change the Rules of the } \\
\text { Governing: }\end{array}$ \\
$\begin{array}{l}\text { The Judiciary } \\
\text { Law Enforcement } \\
\text { Regulation Agencies }\end{array}$ & $\begin{array}{l}\text { Political Opponents } \\
\text { Critical Media }\end{array}$ & $\begin{array}{l}\text { Legislation } \\
\text { Constitution }\end{array}$ \\
\hline
\end{tabular}

Source: Developed by the authors from Levitsky \& Ziblatt (2018). 
However, there is hardly any systemic and comparative work to check the applicability and the reliability of these steps. Thus, there remains significant research gap on the process of democratic backsliding in the existing literature. This paper addresses this gap by applying Levitsky \& Ziblatt's steps as a theoretical framework for a systemic and comparative analysis. Notwithstanding, we offer a slight modification of this model in analyzing six selected cases. Going one step back to mark how the process unfolds, we offer the argument that there are specific identifiable milestones which accentuate democratic erosion in these cases. By referring specific milestones, we point out a catalyst in each case that started out the process of backsliding and provided legitimacy to the incumbent with to continue the process of backsliding. The significance of these catalysts lies in the mark of a consistent decline in democratic performances which never return to the original positions in these cases (Figure 1). A detail discussion of these milestones is presented in the next section.

Figure 2: Democracy Score of Bangladesh, Bolivia, Mali, Turkey, Ukraine, and Zambia, 2007-2019

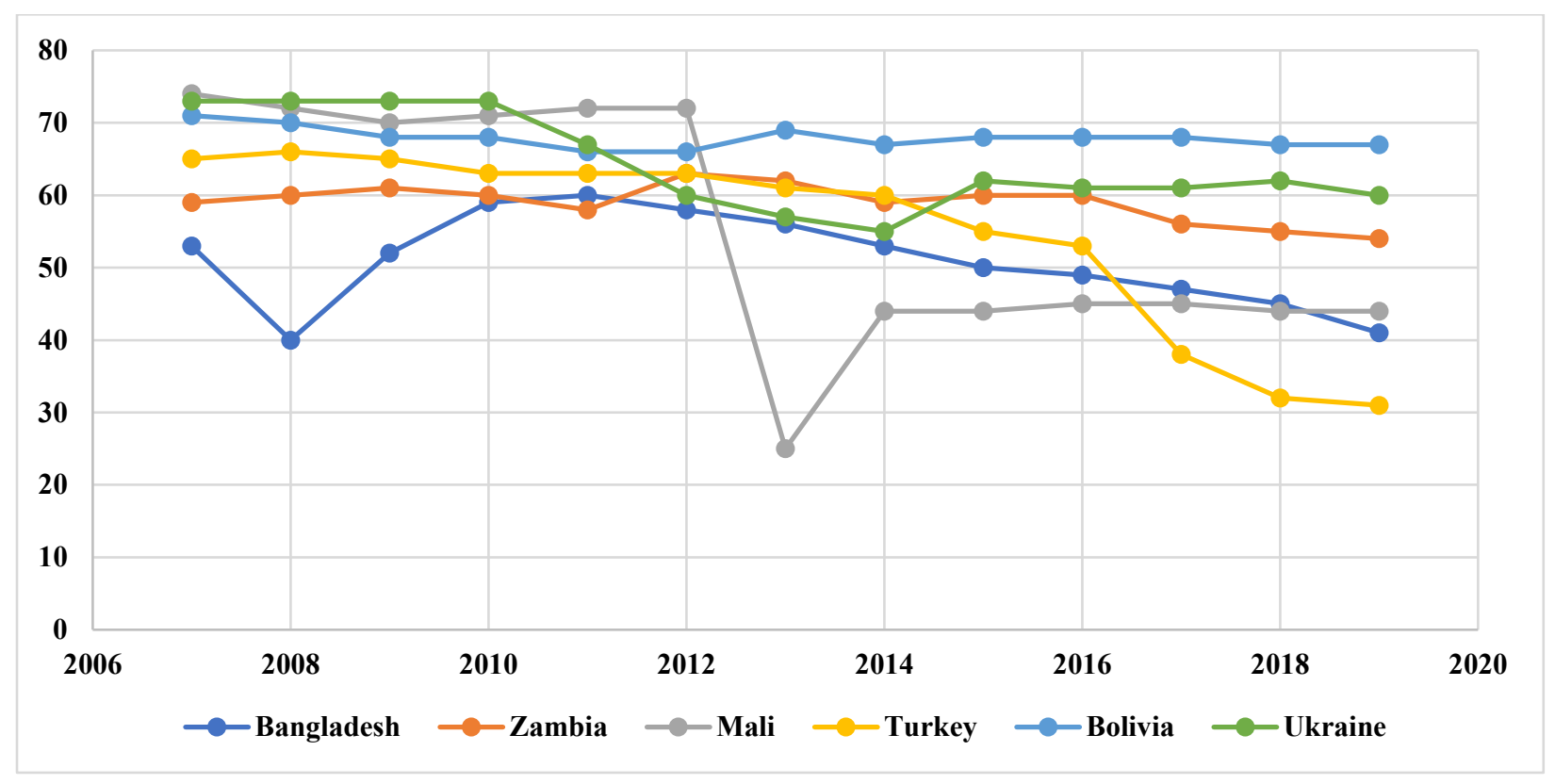

Source: Authors compilation from Freedom House Annual Reports, 2007-2020.

Further, as opposed to Levitsky \& Ziblatt, we argue that changing the rules of the game or making constitutional changes is the first step of backsliders targeting judiciary, electoral system, legislation, rule of law, and civil liberties. Followed by the first step, media become the second target of backsliders in the democratic backsliding process. We also argue that the backsliders' actions against the constitution and the media can go hand in hand throughout the process. The next section explores these arguments in six comparative cases. 


\section{The Process of Democratic Backsliding: Evidence from Six Countries}

\section{Bangladesh}

As Figure 2 indicates, Bangladesh's democratic score began to decline in the year 2011, which serves as a key milestone in tracing the backsliding process. Trends in Bangladesh's Freedom House democracy score suggest that since the Awami League (AL)'s ascendance to power in 2009, the country's democracy score registered an upward trend, but it began to fall in 2011. One of the most critical events in Bangladesh politics was the fifteenth amendment of Bangladesh's Constitution in 2011. Using two-thirds majority in national parliament, Sheikh Hasina government targeted the constitution and abolished the caretaker government (CTG) system. The CTG system stipulated the election will be held under a non-partisan cabinet. The amendment replaced the provision and required elections be held under the incumbent. As there exists zero trust between the ruling AL and the main opposition Bangladesh Nationalist Party (BNP), the amendment engendered protests and violence, resulting arrest and harassments of hundreds of party leaders. It cost 169 deaths and more than 17,000 injuries during the clashes in 2012 alone (Freedom House 2013, 69). It not only intensified general political disfunctions but also paved the way to destroy the democratic opponents and delivered unrestrained power to the incumbent to manipulate elections.

The amendment, passed by the parliament in the absence of the opposition on 30 June 2011 clearly indicate that Constitution was the first target of the incumbent to change the rules of the game (Majumdar, 2013). The most critical in this amendment was the removal of the provision of the non-political caretaker government (CTG), which, was added in the Constitution through thirteenth amendment in 1996. The thirteenth amendment required that parliamentary elections be held under a non-partisan CTG, headed by the immediate past Chief Justice of the Supreme Court appointed by the President to oversee election (Riaz, 2013b; Riaz, 2019). According to Article 58B (1) of the Bangladesh's Constitution (thirteenth amendment), the tenure of the CTG will ensue after the completion of the term of the previous government or after the parliament is dissolved ahead of its expiration, and it will remain in power until a new Prime Minister takes office (CommonLII, 2004). But, after the adoption of the fifteenth amendment, Article 123 (3) states that "A general election of the members of the Parliament shall be held in the case of dissolution by reason of expiration of its term, within the period of ninety days preceding such dissolution" (Laws of Bangladesh, 2020). It implies that the elections will be held at a time when the incumbent will be in office (Riaz, 2013b). PM Hasina had also reiterated this claim stating that the next parliamentary election will be held under the authority of the present government so that no unelected government can assume in power (The Daily Star, 2011).

In addition to the removal of CTG provision, the fifteenth amendment has also added Article 7A and 7B. Article 7A notes that abrogation and suspension of this Constitution and any of its article shall be considered as an act of sedition and the person responsible for such act shall be sentenced with highest punishment (Laws of Bangladesh, 2020). Article 7B prohibits any further amendments of at least 55 clauses which are considered as basic structure of the Constitution (Laws of Bangladesh, 2020). The opposition party BNP and its allies launched violent protest the ruling party's decision to remove CTG provision and, but the government remained adamant in its position and used repressive measures to control the opposition, resulting injuries, 
deaths, disappearances, extrajudicial killing, and imprisonment to many opposition leaders and supporters (Riaz, 2013a; Freedom House, 2013; Human Rights Watch, 2013). Bangladesh's decision to amend the Constitution again demonstrates that the backsliders' first and foremost target in the process of backsliding is Constitution, which have been used to legitimize as well as strengthen their rule.

The sixteenth amendment was passed in September 2014 which gave the Parliament power to remove Supreme Court judges from their office due to their misconduct and incapacity. According Article 96 (2), "A judge shall not be removed from his office except by an order of the President passed pursuant to a resolution of parliament supported by a majority of not less than two-thirds of the total numbers of members of the parliament on the ground of proved misconduct or incapacity" (Laws of Bangladesh, 2020). Article 96 (3) authorizes the parliament to regulate the procedure, investigation, and proof of the misconduct and incapacity of the judges (Ibid). However, reforming the Constitution to serve the interests of the ruling parties has been in practice in Bangladesh politics for decades (Khan, 2015). Many indicated such attitudes of the ruling regime as incumbent theft (Basu et al. 2017) as well as making the legislature a tool of authoritarian move (Riaz, 2019). The consequences of these actions strengthened the ruling regime's position in power and gave strength to target other institutions of the state throughout the process of backsliding.

In Bangladesh's process of democratic backsliding, the incumbent's second target became media as revealed in 2012 when the signs of intolerance by the government became palpable. While print media was given limited freedom in covering some sensitive issues, transmissions of several television stations were suspended and journalists continued to receive threats, harassment, and attacks (Freedom House, 2013, 69-70; Earb, 2012). According to local human rights body, Odhikar, between 2011 and the first half of 2012, at least 3 journalists were killed, over 200 were injured, and over 75 were assaulted (Odhikar, 2013). Many believe that violence against media and journalists are encouraged by the government, which are often reflected by the ruling party leaders' comments against (South Asia Journal, 2012). Government has also increased censorship at internet-based content and even implemented imprisonment for commenting against Prime Minister (Freedom House, 2013, 69-70). In 2013, the government amended the Information and Technology Act 2006, and added the section 57. The new provision allowed the government to file cases against individuals which the government considered has potential to disrupt the country's law and order with a maximum penalty of 14 years imprisonment. The law was designed to muzzle all sorts of dissent and cases were filed mostly by ruling party men (Ahmed 2013).

Such censorship and harassment to media personnel continued in the later years. In 2014, three journalists were killed, and government continued using the Information and Technology Act to arrest and charge several individuals for their online content (Freedom House, 2015, 6667). The government's censorship on media continued against both individuals and media firms through surveillance and the creation of several legal instruments. The National Mass Media Policy in 2017 was institutionalized which closely monitors the content and activities of the media industry in Bangladesh (Human Rights Watch, 2018; Human Rights Watch, 2020). In 2018, the Digital Security Act was passed in the parliament anyone using digital services to spread negative propaganda against the Liberation War or the Father of the Nations might receive life sentences, 
up to five years of imprisonment for deliberately publishing defamatory or false content, and up to ten years of imprisonment for hurting religious sentiment or causing deterioration of law and order (Digital Security Act, 2018; The Business Standard, 2019). The National Broadcasting Act was passed in 2018, which provides sentences up to three years of imprisonment for going against the Spirit of Liberation War (Choudhury, 2019).

Adoption of the legal measures and the widespread use of these by the government and the ruling party activists became a threat to the media and freedom of expression beginning 2013 . The Global Expression Report 2018-19 stated that the average score of freedom of expression and media is significantly below the regional average in terms of digital protection and transparency (The Business Standard, 2019). The incumbent's use of judiciary to silence the media, arbitrary blocking of news websites, and strict government measures on media freedom, harassment and attacks on journalists contributed to decline in media freedom in Bangladesh, as the World Press Freedom Index 2019 suggested (World Press Freedom Index, 2019; Dhaka Tribune, 2019). Bangladesh has also been using the Bangladesh Telecommunication Regulatory Act to impose surveillance and control of media (Riaz, 2020).

\section{Bolivia}

Although democratic erosion in Bolivia started at the beginning the twenty-first century, the year 2009 played a pivotal role in accelerating the democratic breakdown. After Evo Morales was elected as the President and his Movement for Socialism (MAS) Party secured a majority in the lower-chamber House of Deputies (though not in the Senate) in 2006, the party promised drafting a new constitution, for which it required a supermajority. Through various machinations, the MAS secured support of smaller independent parties and passed the draft of a new constitution amid violent confrontations between Morales supporters and opposition camps and bypassing the opposition. The referendum in 2009 on constitution which delivered Morales a victory with 67 percent votes, and MAS two-thirds majority in both houses of legislature, accentuated the past phase of democratic backsliding, as indicated by Figure 1.

The demand for amending the Bolivian constitution was not new, but Morales administration, after ascending to power in the second term in 2010, made changes which changed the rules of the game in favor of incumbent and contrary to democratic spirit. For example, the removal of presidential term limit from the Constitution. According to Article 87 (I \& II) [Second Title] of Bolivia's 2005 Constitution 2005, the term for the President and the Vice President of the Republic was five years and, non-renewable. It stipulated that "the President may be re-elected once only after at least once constitutional term has elapsed" (Political Database of the Americas, 2005). In contrast, the Morales regime-led 2009 Constitution added Article 168 [Title II], stipulated that, "The period of the mandate of the President or the Vice President is five years, and they may be re-elected once for a continuous term" (The Constitute Project, 2020). This change provided Morales legal authorization to continuously serve for a second term (Walsh, 2010, 252). 
The changes in the constitution also encroached into judicial independence, a crucial element of democracy. President Morales also attacked Bolivia's judiciary by publicly criticizing the judges of the Constitutional Courts (International Bar Association, 2007). The new Constitution added vague clause on judicial independence. Article 178 (II) states that "the guarantees of judicial independence are: (1) the performance of the judges in accordance with a judicial career; and (2) the budgetary autonomy of the judicial bodies" (The Constitute Project, 2020). It is unclear whether the Judiciary has a substantive right to decide the law (Walsh, 2010, 253).

Armed with these changes and moving beyond, Morales managed to stay in power for the third consecutive term starting in 2014 with 60\% votes (The Guardian, 2014). While the constitution approves only two terms, his third term was approved by the court, which appears to have lost its independence, on the ground that Morales' first term should not be considered because it predated the 2009 constitution (BBC, 2013). In February 2016, Morales regime held a constitutional referendum to allow Morales to run for a fourth consecutive term. Most of the Bolivians voted against Morales' fourth consecutive term (Collyns \& Jonathan, 2016), but the Constitutional Court allowed Morales to run for a fourth consecutive term and beyond (BBC, 2017; Farthing, 2017). Violent protests broke out during October 2019 elections and Evo Morales was forced to resign from the government (Londono, 2019). By the time Morales resigned, the country had become an authoritarian system.

The 2009 constitutional changes which allowed Morales to stay in power was followed by a series of legislative actions undermining the freedom of press and media. A new electoral law was passed in 2010, particularly Article 82 of the law, restricted coverage of judicial elections, prohibited publishing any information about the candidates which were not released by the electoral authorities (Freedom House, 2013b). In July 2011, the Bolivian Senate approved the 'Telecommunications, Information, Technology and Communication Law', which gave the state significant control over electronic media. Article 11 of the law provided 33 percent of the broadcast spectrum to both state and private sector, but Article 111 allowed state to intervene telephone conversations in cases of national security, foreign conspiracy, and threat to law and order (Lara, 2011; Freedom House, 2013b). Many argued that the new law would allow Morales to have 66 percent control of the radio and television broadcasting and oblige telecommunication providers to cooperate with state authorities (Lara, 2011). Beside continuously harling verbal abuse to journalists, Morales was using state-owned TV channels and newspapers to propagate its ideology and political propaganda (Dagron, 2012). For example, the state-owned the Canal 7 Television Network (Bolivia TV) and the state-financed national newspaper Cambio were particularly devoted to give wide coverage on the activities of the President and the ruling party (Dagron, 2012).

Morales regime used legal mechanism against the media. In 2012, government filed charges against the news agency Fides (ANF) and the newspapers El Diario and Pagina Siete for 'distorting' the President's words in a speech in which, according to these media outlets, president blamed lazy people responsible for hunger in the eastern part of Bolivia (Freedom House, 2013b). In a book titled 'Remote Control' published in 2014, Bolivian journalist Raul Penaranda exposed that President Morales created media network of TV channels and national dailies, which were 
ostensibly privately owned by government sympathizers but were indirectly controlled by the government as they receive huge government funding and ceded editorial and informative control to the office of the Vice President (Martinez, 2014). The book, written based on interviews with government officials and media personnel, provided evidence that television channels e.g. ARB, PAT, Full TV, Abya Yala and the largest circulated national daily La Razon are owned by Carlos Gil who is a Venezuelan entrepreneur and a friend of Morales (Martinez, 2014). The following years have also witnessed repressive government actions to harass media personnel and undermine media freedom which further contributed to the decline of democracy in Bolivia.

\section{Mali}

In Mali, the March 2012 a military coup d'état ousted the democratically elected government and led to a sharp decline of Mali's democracy which never returned to the pre-coup status. During the rule of Mali's President Amadou Toumani Touré (popularly known as ATT), who ran 2002 election as an independent candidate with the support of his apolitical association, Citizens Movement (MC) and won, appointed a large number of members from various political parties and MC. This strategy, what ATT called 'consensus politics', limited the development of a strong opposition (Bleck, 2012), and severely undermined decentralization approach, which had been considered as a hallmark of Mali's democracy. The consensus politics also have incentivized rampant corruption and patronage among political elites (Arieff, 2013), which on the one hand, centralized power and privileges among government elites, and on the other hand, proved to have lack of local governance and government accountability in achieving social and economic rights of the mass people.

This political landscape fueled the decades-long insurgency movement of the Tuareg community, a semi-nomadic small minority in the Northern Mali. The community had been alleging that successive governments have discriminated, marginalized, and neglected the region. They allege that lack of public services, and poor infrastructure in the north was due to the southcentric government since Mali's independence. The Tuareg rebels, after returning from the Libyan conflict in 2011, declared the independence of Northern Mali while the ATT government was planning for greater control of potential oil and gas resources located in the region. In January 2012, The Tuareg rebels' organization the Nationalist Movement for Liberation of Azawad (MNLA), along with the Islamist extremist group Ansar Dine, and terror group Al Qaeda of Islamic Maghreb (AQIM), launched targeted attacks on military establishments in Northern Mali and secured victory (Bleck \& Mitechlitch, 2015).

Being frustrated by the defeat in the North due to inadequate arms and supplies and poor government response, Mali's military soldiers staged a coup and removed the President in the South in March 2012, a month ahead of the scheduled national election. The military junta led by Captain Amadou Sanogo immediately suspended the constitution, arrested senior military officials and ministers loyal to deposed President ATT, and handed over the power of transitional government to Dioncounda Traore, President of the National Assembly, though the true power 
resided in the hands of the military. The Prime Minister Cheikh Modibo Diarra, appointed by President Traore, headed the preparation for the presidential and the parliamentary elections. The existence of a triangular form of authority among the military junta, President Traore, and the Prime Minister Diarra led to political volatility and widespread confusion among the people about the future of the state. Taking advantage of this political chaos in the capital, the rebel groups took control of the northern regions of Timbuktu, Kidal, and Gao, and declared the independence of Azawad. While they were attempting to occupy southern regions, they were eventually prevented by the French soldiers, initially requested by Malian government.

However, once the situation came under somewhat control, the transitional government hold presidential election in May 2013, in which Ibrahim Boubacar Kei'ta won presidency and sworn into office. Under the leadership of President Kei'ta, since 2013, Mali's democracy, has not been able to reach even close to the pre-coup level, although it has seen some degrees of improvement in any areas. Thus, the 2012 coup has been a key milestone in Mali's political fragility and a breaking point of Mali's democracy.

In case of Mali, the 2012 military coup accentuated Mali's democratic backsliding and constitution remained top priority throughout the process of backsliding. The attempts to constitutional reform had been an integral part of politics since the beginning of democratic erosion in early 2000s. As of July 2020, three constitutional review initiatives have been proposed under different administrations. While President Konare's proposed constitutional amendments in 2001 was declared unconstitutional by the Constitutional Court, President Toure's review initiatives led to the widespread protests led by civil society organizations and political opponents with the slogan - 'do not touch my constitution' (Bamassa \& Aboubacar, 2016). Many also argued that the controversies induced by the proposed constitutional reforms by President ATT, along with the insurrection of the Tureg rebels, pushed Mali into a political crisis which provided the ground for the 2012 military coup to happen (Wing, 2015, p. 453).

The first target of the coup leaders was constitution and they immediately dissolved the constitution and replaced it with new fundamental law for Mali, though they had to reinstate constitutional order due to international and regional pressure (Bamassa \& Aboubacar, 2016). The 2012 coup and post-coup political crisis led Mali's democracy to decline even under President Keita. Changing the rules of game through constitutional amendment has remained as a top priority of the incumbent. President Keita-led constitutional amendment initiative in 2016 included significant changes including the establishment of a bicameral parliament composed of a Senate and a National Assembly, decentralization, and recognition of regions with their own executive body (Diwara, 2017).

However, the proposed constitutional amendments would have given extra power to the President (Reuters, 2017). Article 38 of 1992 Constitution provided the President the power to appoint the Prime Minister and set limits on the PM's powers (Mali's Constitution of 1992). But the proposed constitutional amendments in 1996 included provisions that would allow the President to nominate as well as terminate the Prime Minister at the will of the President (Diwara, 2017). Additionally, Article 92 of Mali's 1992 Constitution states that, "The President of the Constitutional Court shall be elected by his peers" (The Constitute Project, 2020a), but the 
proposed amendment allowed the President to retain the power to nominate the president of the Constitutional Court (Diwara, 2017). The proposed constitutional amendments would also allow the President to elect a third of Senate members, dissolve the National Assembly upon consultation with the Prime Minister and the Speaker, and preside over the Higher Council of Magistracy that decides important issues such as appointments, promotion, and dismissal of judges (Diwara, 2017; Sangare, 2017).

The freedom of media had long been hailed as freest among African countries and the evidence as such could be found since there was no sign of harassment or intimidation of journalists as well as government attempt to control media in between 2007 and 2011 (Freedom House, 2013c, 44-7). However, with the 2012 military coup, that fast-tracked democratic decline in Mali, media were targeted and repressed by the government. In the aftermath of the coup, there were reported incidents of arbitrary arrest of unprecedented number of journalists and newspaper editors, takeover of broadcast stations, restrictions of media reporting in the South due to coup, and closure and takeover of media outlets and torturing of journalists in the north by the Islamist militants (Freedom House, 2013d). The coup leaders not only restricted news and banned interviews with deposed president, but also stormed the state broadcaster, the Malian Office of Radio and Television Broadcasting (ORTM) and used it as headquarters of the military (Ibid). In the post-coup Mali, the civilian government had also continued to suppress media freedom as claimed by the Reporters Without Borders in 2013 that the government has been censoring news reporting on the government abuses in the Northern Mali (Freedom House, 2015, 428).

Bribery and threats to control media content were also rampant in recent years in Mali (Freedom House, 2016). In March 2015, state authorities blocked the news magazine Le Reporter's issue being published as it refused to refrain from publishing critical content against two members of legislature (Freedom House, 2016). After one month, the National Assembly approved the establishment of the High Authority for Communications (HAC), in which six out of nine members will be chosen by the President and the National Assembly (Freedom House, 2016). The later years saw a slight increase in government attempts to curtail media freedom as there had been scattered reports of censorship and threats against journalists (Freedom House, 2018, 606). Government also convicted and imprisoned journalist Amy Baba Crisse of the Le Figaro newspaper in 2017 for 'defaming' the President of the National Assembly on the ground that defamation is a crime as per Mali's constitution (Freedom House, 2018, 606). There had reported incidents of intimidation, harassment, and death threats against journalists and bloggers regarding reporting on upcoming constitutional referendum and general elections in 2018 (Freedom House, 2018, 606). In addition, government increased restrictions on media licenses and shut down approximately 50 radio stations for allegedly operating without license shortly before the scheduled constitutional referendum (Freedom House, 2018, 607).

These patterns of manipulation have pushed Mali's democracy towards an uncertain future. The 2020 political crisis in Mali offers evidence in this regard. In face of a mass protest due to rampant corruption, dwindling rate of poverty, and mishandling of security situation by the President Keita regime especially after his re-election in 2018 which was marked by serious electoral irregularities, Mali's prime minister and the cabinet resigned. President Keita, however, 
refused to step down from power and formed a new cabinet to deal with the situation (Felter \& Bussemaker, 2020). The protesters' insistence of Keita's resignation and several armed groups' deep resentment against the ruling regime may push the country to the brink of a civil war.

\section{Turkey}

Perhaps more than any other cases of this study, Turkey's political developments since 2007 demonstrate that the constitution is the first and foremost target in the process of democratic backsliding. Democratic reversal in Turkey began with the victory of Recep Tayyip Erdoğan and the Justice and Development Party (AKP)'s for the second time in 2007 elections. Unlike of 2002 general elections, Erdogan's party won 46 percent of votes in 2007 elections and maintained a comfortable majority in the parliament against the main opposition, the Republican People's Party (CHP), which is a party of armed forces, bureaucrats, judges, and academics (Akyuz \& Hess, 2011).

Contrary to his previous tenure as Prime Minister, Erdogan, after 2007, turned out to be the sole leader of the party and the the government. One of the key reasons behind this was imbalance in power configuration inside the AKP. In 2002-2006 cabinet, Foreign Minister Abdullah Gul wielded almost equal power and acted as a balancing and moderating force on Erdogan (Cornell, 2014). Bulent Arinc, the Speaker of the parliament and perhaps the most outspoken Islamist in the ruling party played a similar role. On the other hand, in 2007-2012 tenure, Gul was elected as President of the Republic and Koksal Toptan replaced Arinc as Speaker. This change in presidency and speaker had two significant implications. First, it ushered the way for AKP to control key levers of state power, leaving little space open for the opposition to influence. In the Republic of Turkey, the President acts as the commander-in-chief of the military, and exercises power to appoint Constitutional Court Judges, higher education board, and university rectors (Kirisci \& Sloat, 2019).

In 2002-2006 period, the President Ahmed N. Sezer was from the opposition party, who managed to maintain a balance of power in the power structure of the Republic. Having President, Prime Minister, and Speaker from the same party, AKP rose as the sole political power center, wielding undivided power to all levels of the government and the state. Second, it opened a window of opportunity for Erdogan to be at the center of the AKP. Unlike Arinc, Toptan was a former minister without an Islamist past and a close ally of Erdogan. Similarly, although President Gul officially had had some powers, he was removed from day to day political matters, paving the way for allowed Erdogan's emergence as the sole power center.

Erdogan-led government, since the arrival at power in 2002 (as the Prime Minister until 2014, then as the President), has made at least four amendments in the constitution of Turkey in 2004, 2007, 2010, and 2017. After being re-elected in 2007, the Erdogan government first targeted the constitution to change the rules of the game as well as to consolidate power. The Erdogan and AKP-led 2007 constitutional amendments included lowering the presidential term limit changing 
Presidential election procedure, expansion of parliamentary supervision over the government budget and the reorganization of supreme board of Radio and Television, and (Coskun, 2013, 102). Article 102 of the 1982 Constitution stipulated that a candidate for the Presidency, if not a member of the parliament, will require nomination form one-fifth of the parliament members, and be elected by securing two-thirds majority in the parliament in the first two rounds and a simple majority in the second two rounds (Constitution of the Republic of Turkey, 1982).

In contrast, the 2007 constitutional amendments proposed direct election for the President in the first two rounds by popular votes (Migdalovitz, 2007, 5). Article 101 of the 1982 Constitution imposed a seven-year one term limit, required resignation from the political party and the automatic cessation of the parliament membership (Constitution of the Republic of Turkey 1982). The 2007 constitutional amendment, on the other hand, changed the term five years and extended the limit to two terms (The Constitute Project, 2011; Migdalovitz, 2007, 5). The tenure of the parliament was reduced to 4 years from 5 years in the Article 77 (Constitution of the Republic of Turkey, 1982; The Constitute Project, 2011). The new amendment also lowered the parliamentary quorum to 184 out of 550 for all legislative matters which would allow a small number of legislators to make decisions for consequential issues for the entire country (Migdalovitz, 2007, 10). Many identified Erdogan's attempt to make these changes in the constitution as a reflection of his autocratic tendencies (ibid, 9).

In 2010, the Erdogan regime amended at least 26 articles of the Constitution (Yegen, 2017, 80 ), of which, the changes in the structure of judiciary and courts are most significant and relevant for this study. The Article 146 of 1982 Constitution noted that the Constitutional Court shall comprised of eleven regular members (Constitution of the Republic of Turkey, 1982). The number was increased to seventeen regular members in 2011 constitution, of which fourteen will be appointed by the President and three by the parliament (The Constitute Project, 2011; Cagaptay, 2010). The 2010 amendment has also increased the number of High Council Judges and Prosecutors from twelve to thirty-four, of which, four will be appointed by the President (Turkey's Constitution 2011). Besides the President's appointments, twelve other members will be appointed by the Minister of Justice, his undersecretary, and government-controlled academy of justice, along with the Justice Minister as chief administrator of the Council, will give Erdogan and AKP enormous power and authority of the Council (Cagaptay, 2010). Apart from gaining broader control in the composition and the procedure of the Judiciary and the Council, the current amendment has also provided restrictions on military court's jurisdiction as well as reduced the role of military in ordinary governance (Bali, 2012, 299; Yegen, 2017, 80).

After being the first Turkish President by popular vote in 2014, Erdogan and AKP government made further amendments in the Turkish constitution in 2017. The 2017 amendments comprise changes in 18 Articles those converted the parliamentary system into a presidential one. The creation of an executive presidency (Article 104) is the most significant change in the history of Turkey since 1950s. The changes have abolished the post of the Prime Minister and reduced the parliamentary oversight on the executive, including not allowing members of the parliament to question the President (Human Rights Watch, 2017). It has given the President the power to appoint and dismiss ministers, legislate by decree, and control judicial appointments (ibid). Through this amendment, the President is now allowed to retain direct affiliation with his party, set the state budget, and broader authority over high council judges and prosecutors (TRTWORLD, 
2017; Bora, 2017). The current version of Turkish constitution has severely weakened the checks and balances on the power of the executive and guaranteed that even the Parliament is not able to place a vote of confidence against the president, while he can dissolve and reinstate at his will (IISS, 2017; Bora, 2017).

The Turkish case shows that the constitution remains the first and foremost target of the authoritarian ruler throughout the process of democratic backsliding. In this case, Erdogan, while being prime minister, strategically changed presidential term limit and presidential election procedure through 2007 amendment, managed to give the president broader control over the procedure and composition of constitutional courts and high council and reduce control of the military through 2010 amendment. After being president, Erdogan used 2017 amendment to convert the parliamentary system into a presidential and enhanced power and authority to the President, thus pushed the country toward an authoritarian drift.

Targeting media by the Erdogan regime began slowly in 2007 soon after the constitutional amendments. Since then, the Turkish government have been applying conglomerate pressure, judicial suppression, online banishment, surveillance, accreditation discrimination to control media (Akser \& Baybars-Hawks, 2012, 303). Journalists, cartoonists, bloggers, and media activists started reportedly facing different forms of interference from government officials (Freedom House, 2009, 736). Erdogan managed to buy off critical media, as in 2007, Turkey's second largest media group Sabah-ATV was sold to Calik Holding company in which Erdogan's son-in-law was the CEO (Freedom House, 2013f, 7). The company immediately received over $\$ 1.8$ billion finance from two state banks and the Sabah-ATV editorial line transformed from center-left to progovernment positions (Ibid). In addition, the Turkish parliament passed a new law in 2007 and revised Article 301 of the penal code in 2008 which allowed the state authorities to block websites for allegedly publishing contents that were deemed insulting to the Turkish nation (Freedom House, 2009, 736). Erdogan's negative attitude towards the media revealed when his government fined $\$ 2.5$ billion on the media group, Dogan Yayin, which was one of the most critical voices against the Erdogan government (Arsu \& Sabrina, 2009).

There had also been many incidents of blocking Kurdish websites (Freedom House, 2011b, 691) and closing Kurdish newspapers in 2012 such as Demokratik Vatan and Ozgiir Giindem (Freedom House, 2013e, 711). The 2012 report of the Committee to Protect Journalists (CPJ), informed that at least 49 journalists were behind the bars, more than any other country in the world, (Freedom House, 2013e, 711). After the Gezi park protests (May 2013), the government fired journalists from state controlled media for reporting the protests, increased sentences of journalists, wiretapping, and buying off or forcing our media moguls (Freedom House, 2013f, 89 ). Most of the media outlets in Turkey are owned by holding companies who earn only a small fraction of profit from media but the bulk of profits come from businesses in other sectors such as mining, finance, and energy (Freedom House, 2013f, 6; Hoffman \& Werz, 2013). In 2015, apart from continuous harassment and imprisonment of newspaper editors, journalists, and even students, government lashed out the offices of the liberal newspaper Hurriyet, began legal investigation against two newspapers Bugun and Millet, shut down two television stations Kanalturk and Bugun TV, blocked access to social media such as YouTube, Twitter, and Facebook, and blocked more than 100,000 websites (Freedom House, 2016, 716-717). After the failed 
military coup in 2016, over 160 media outlets and publishing houses have been shut down and over 140 media personnel were imprisoned (Human Rights Watch, 2017) and the ruling party extended further control over the media (Jones, 2018).

\section{Ukraine}

President Yanukovych's assumption of Presidency in 2010 is a watershed moment in the history of Ukraine. After winning the election in February 2010, he targeted the 'referees' by allying himself with the legislative bodies to bring changes in law and constitutions. As Yanukovych could not secure two-third majority in the election, he made an alliance with parliament speaker who gave him enough votes to replace the prime minister and change the law on parliamentary procedure to allow floor-crossing, that is individual deputies to defect from their party and join the government coalition (Freedom House, 2013a). This provided the President the necessary parliamentary majority to make changes in the constitution later that year and concentrate power at his hand (ibid).

The government also made its move in the first year of its arrival in power to change the rules of the game. With the constitutional amendments in October 2010, Yanukovych consolidated power at his hands. The new constitution allowed him the right to appoint and dismiss the Prime Minister, other members of the government, other heads of national executive bodies, and heads of provincial and local administrations (Tolksdorf, 2014). Also, reorganization of the government establishment and liquidation of national executive agencies are now included as functions under the sole jurisdiction of the President of Ukraine, who can also repeal the acts of the Cabinet of Ministers and of the Government of the Crimean Autonomous Republic within Ukraine (Trochev, 2011). Together these reforms turned the parliamentary system into a presidential parliamentary one.

Also, the constitutional reform also led to approval of new electoral rules in 2011. One key issue in this regard is whether the parliament will be chosen based on proportional representation, or whether 50 percent of the members will be selected through a majoritarian system, which would make it more difficult for smaller parties to compete, would in any case favor the incumbent Party of Regions (Kramer et al, 2011, 7-8). However, after Yanukovych fled the country in 2014, the constitutional reforms in 2014 and 2016 restricted the president's power and enhanced the power of the judiciary and supreme court in Ukraine. Although democracy scores in Ukraine has improved in recent years in comparison to Yanukovych regime, legacy of the authoritarian practices have remained in place and continue to undermine democratic norms and institutions.

In Ukraine, in October 2010, the government launched legal and administrative procedure to monopolize media outlets under state control. For example, the setup of the National Broadcasting Council, as the state regulator of broadcast media, reversed all the decisions related to digital broadcasting licenses it had made over the previous three years and took control of the country's media outlets (Kramer et al., 2012, 10). On the face of the weak foundation due to the Orange Revolution and the national crisis, derived from the Russian intervention in 2012, 
government took administrative measures to restrict media freedom and numerous cases were reported on harassments and assaults on journalists and reporters (Freedom House, 2019, 10).

\section{Zambia}

In Zambia, although democracy has been performing poorly since the beginning of 2000s (Simutanyi, 2010, 3-4), the dramatic decline began after President Rupiah Banda's rise to power (2008) and the constitutional changes in 2009. Banda assumed Presidency in the context of political uncertainty due to the sudden death of President Levy Mwanawasa in August 2008 (Cheeseman \& Hinfelaar, 2009, 51-52). Although Zambia officially ended the one-party state system on 1991, the ruling Movement for the Multiparty Democracy (MMD) has all the power at its disposal and Banda was not shy in using those.

Under Banda administration (2008-2011), Zambian politics was characterized by contentious politics, increasing corruption, suppression of opposition, and infringements of civil and political rights (Freedom House, 2011, 746). During Banda's office, the Supreme Court's dismissal of Michael Sata and Patriotic Front (PF)'s appeal about the election's validity reflected the strong influence of the Executive in Zambia's judicial system (Lansner, 2011, 2). With the 2011 presidential election in mind, confrontational political environment was created by the ruling party since 2009. While the MMD-led pro-government forces continued using repressive measures to dominate the opposition and government's influence for election campaigns, the major opposition parties such as the PF and the United Party for National Development (UPND) joined hands together to challenge the MMD-rule (Lansner, 2011, 2-3). The 2011 elections, delivering the victory to Michael Sata of the PF, changed the party in power, first in 20 years. However, democratic decline continued, and gradially took pace. but also accelerated. The democracy score for Zambia started falling from 61 in 2009, reaching 54 in 2019 (Figure 2).

Despite the introduction of multi-party system in 1991, MMD retained its power and behaved like the hegemonic party. It often targeted the constitution; a series of amendment attempts are taken since the constitutional review process began in 2002. However, the changes began to take shape under Banda presidency. Based on the National Constitutional Conference (NCC) ACT, created in 2007, President Banda resumed the constitutional reform works in 2009 with an eye on the 2011 general elections. The NCC's final report for a new constitution in 2010, although incorporated several new provisions, for example increasing number of seats from 150 to 280 in the legislature, a mixed-member proportional electoral system, and regulation of political parties. But it did not attempt to decrease the presidential powers or increase the power to legislature to create check and balance to executive power (Simutanyi, 2013, 39). Article 33 (1\& 2) of Zambia's 1996 Constitution made the President the Commander-in-Chief of the Defense Force (Constitution of Zambia 1996).

The opposition parties demanded for changes in such powers of the President as well as urged for 50 percent plus one vote requirement for the election of the President, the Vice President 
as running mate, appointment of ministers from outside the legislature, and three-month transition period before a new president is sworn in (Simutanyi, 2013, 40). The ruling MMD government rejected these demands as they would reduce presidential power and authority. No consensus among the political parties emerged and the constitutional amendment bill failed to receive parliamentary approval in 2011 (Simutanyi, 2013, 39-40).

Though not much changes in the executive powers of the president, the 2016 constitutional amendment made vast changes in the constitution. Of which, two significant changes, relevant to this study, affected Zambia's governance. First, a devolved system of governance through provincial administrations was added in the constitution. According to Article 149 (1) of 2016 Constitution, the President, with the approval of the National Assembly, may create or divide a province or merge two more provinces (Constitution of Zambia 2016). This undermines popular participation in governance and possible resolution of Barotseland (a contested region of Western Zambia)'s demand for self-determination) issue (Munalula, 2016). Second, a mixed-member electoral system has been added in the constitution combining proportional representation (PR) and first-past-the-post (FPTP), as enshrined in the Article 47 (1 \& 2) in the 2016 Constitution (Constitution of Zambia 2016). It has also increased the number of elected members to 250 in a bloated parliament, which might create trouble for budgetary and cost management (Munalula, 2016). Though many argued that the 2016 amendment was not a people-driven constitution (Lumina, 2016), it secured majority votes in the 2016 constitutional referendum and became law of the country (EISA, 2016).

In 2019, the incumbent proposed further reforms of the Constitution. These reforms proposed to enhance the power of the President by handing over the authority to appoint in several positions without effective oversight. It has removed the role of the Constitutional Court if the National Assembly fails to affirm presidential nominees. It has removed the role of civil service commission, judicial service commission, and state audit council in the appointments of key posts in the cabinet, treasury, public protector, and auditor general (The Constitution of Zambia [Amendment] Bill, 2019; Lumina, 2019; Commonwealth Lawyers Association, 2019). The President will be able to select deputy ministers as well as nominate candidates for these positions in consultation with the National Assembly (Lumina, 2019; Oneko, 2019). Under the proposed constitution, the cabinet will be headed by the president, thus the National Assembly will have little oversight over the cabinet. It provides the President the authority to approve public loans.

A key provision about the judiciary of the current constitution is proposed to be removed. Article 143 (a) of the Zambia Constitution currently provides that 'a judge shall be removed from office on the following grounds: (a) a mental or physical disability that makes the judge incapable of performing judicial functions; (b) incompetence; (c) gross misconduct; or (d) bankruptcy.' But the Amendment Bill replaces subsection (a) and allows for removal when a judicial officer is 'legally disqualified from performing judicial functions.' It undermines judicial independence in the removal of judges. (Lumina, 2019; Commonwealth Lawyers Association, 2019). If the proposed 2019 constitution is passed, it would give enormous power to the President which would further deteriorate the democratic decline in Zambia. 
Although there had been an increase in government's approval of media outlets in Zambia since 2008 (Simutanyi et al., 2015), government's control of media had also begun appearing since then once democracy started declining. In 2008, Banda obtained court order to forbid the leading independent newspaper The Post (Freedom House, 2009a, 798). There had also been reported incidents of harassment of reporters and journalists of independent station Radio Phoenix and Catholic-owned Radio station by police (Ibid). Government and pro-government media houses have had a lot of influence on media. For example, government controls two widely circulated Zambian newspapers e.g. Zambia Daily Mail and Times of Zambia and the state-owned Zambia National Broadcasting Corporation (ZNBC) dominates broadcast media (Freedom House, 2011, 747; Kabwe, 2009). Government also retains the right to appoint members of the management boards of ZNBC and the Independent Broadcasting Authority (IBA) (Freedom House, 2014, 772).

The incumbent has often used these channels to suppress media freedom. For instance, the secretary of IBA was fired in 2013 due to his rejection to President Sata's order to revoke the license of privately owned media outlets - Radio Phoenix and Q-FM for broadcasting insulting statements of opposition politicians against the government (Freedom House, 2014, 772). The year also saw that Zambian government blocked the access of two news websites namely Zambian Watchdogs and Zambia Reports for allegedly publishing inflammatory language against the government authorities, harassed journalists and reporters who run these websites, legally charged against the editor of the Daily Nation for publishing false news (ibid).

Media outlets that hosted and published statements and criticism of the opposition parties against government have also faced the wrath of the government repressive actions even during their live broadcast. In 2015, the PF-led government's Central Province Minister ordered the dissolution of UN-supported Mkushi Radio for being biased toward the opposition party UPDN, while the Information Minister threatened to revoke the broadcasting license of Radio Phoenix for allegedly disseminating anti-government propaganda and fired ZNBC radio producer for publicly criticizing the minister (Freedom House, 2016, 778). There has been reported incidents of PF supporters' disrupting live broadcast of Breeze FM while featuring opposition politicians, attacking reporters of the Post, and vandalizing the offices of Radio Icengelo (ibid). Government also shut down the Post before 2016 elections blaming on tax debt and threatened to shut down the Mast, which declare to continue the work of the Post (Freedom House, 2018, 1108).

\section{Conclusion}

In analyzing the process of democratic backsliding in six comparative cases, we have showed a sequencing of the process. We have built on the on the model of Levitsky \& Ziblatt but revised it by demonstrating that backsliders target the rules of the governing to begin with. These case studies have shown that the constitution become the first target of the incumbent to shape the trajectory. While the backsliding is an incremental process, as we have demonstrated in these six cases, there were milestones that accentuated the processes and allowed the incumbents to proceed under the democratic garb. These key milestones acted as catalysts. We have found three identifiable 
milestones in six cases: winning a large majority in election (Bangladesh) and constitutional referendum (Bolivia), re-election of authoritarian-minded leader (Turkey \& Ukraine), and unexpected events such as military coup (Mali) and death of an incumbent (Zambia). Additionally, in the process of backsliding, the first target of the autocrats is to make constitutional changes to accumulate power at the hands of the executive. We find that the constitutional changes are mainly directed towards four areas: rule of law, judiciary and legislative, election and civil liberties, and freedom of expression and association. Furthermore, after constitution, media manipulation is the second target of the autocrats. Media freedom is undermined by passing new legislation, applying conglomerate pressure, patronizing state-financed media outlets, applying online content control and censorship, and harassing the media personnel.

Each of these cases have displayed at least one of the three characteristics of democratic backsliding identified by Nancy Bermeo - promissory coup, executive aggrandizement, and strategic manipulation of election. The most palpable of these three characteristics in six cases we have discussed is the executive aggrandizement, which in many instances paved the way for manipulating the election and consolidate the incumbent's power. In each instance, the executive has targeted the constitution and amended various provisions to grab more power. Morales of Bolivia, Erdogan of Turkey, Yanukovych of Ukraine have not only grabbed the power but exercised those to extend their tenure through manipulation of elections. Executive aggrandizement has not been limited to grabbing power by individuals but by the executive, as the case of Zambia amply demonstrates. Despite change of incumbent party and the President, blatant efforts to extend the power and authority has accentuated. In case of Bangladesh, the existing constitution had already provided significant power to the Prime Minister over the legislative body and the ruling party, especially because of the anti-defection clause (Article 70); thus, constitutional amendments did not require any new arrangement. In this instance, simultaneously holding several positions - the Prime Minister, the Leader of the House, President of the party have already provided significant power to shape the legislative and executive actions. The other characteristic of the democratic backsliding is also discernable in many of these instances strategic manipulation of the elections by the incumbent. Bangladesh's two elections, in 2014 and 2018, are the glaring examples, so is the case of Bolivia.

As such, these case studies make two contributions. First, it underscores the need to focus on the catalysts and milestones of the countries which has already experienced the democratic backsliding. Secondly, it should help us identify the countries which are at the early stage of the backsliding, to follow it more closely and perhaps interject in the process by devising ways to stop the process on the track. 


\section{Bibliography}

Akser, Murat and Banu Baybars-Hawks. 2012. "Media and Democracy in Turkey: Toward a Model of New Liberal Media Autocracy." Middle East Journal of Culture and Communication 5: 302-321.

Akyuz, Kadir and Steve Hess. 2018. "Turkey Looks East: International Leverage and Democratic Backsliding in a Hybrid Regime.” Mediterranean Quarterly 29(2): 1-26.

Andersen, David. 2019. "Comparative Democratization and Democratic Backsliding: The Case for A Historical-Institutional Approach.” Comparative Politics 51(4): 645-663.

Arieff, Alexis. 2013. "Crisis in Mali." Congressional Research Service (CRS). Retrieved January 14, 2020 (https://fas.org/sgp/crs/row/R42664.pdf).

Arsu, Sebnem and Sabrina Tavernise. 2009. “Turkish Media Group Is Fined \$2.5 Billion”. The New York Times. Retrieved August 10, 2020 (https://www.nytimes.com/2009/09/10/world/europe/10istanbul.html).

Bali, Asli U. 2012. "The Perils of Judicial Independence: Constitutional Transition and the Turkish Example.” Virginia Journal of International Law 52(2): 235-320.

Bamassa, Sissoko and Guisse Aboubacar. 2016. "Mali's promising constitutional reform process: Cementing peace through devolution of power." The Constitution Project, International IDEA (Institute for Democracy and Electoral Assistance). Retrieved October 15, 2019

(http://constitutionnet.org/news/malis-promising-constitutional-reform-process-cementing-peace-throughdevolution-power).

Basu, I., Divine, J. \& Wood, G. 2017. "Introduction: Contesting Political Space - Who Governs in Bangladesh." In Politics and Governance in Bangladesh: Uncertain Landscapes, eds. Ipshita Basu, Joe Divine, and Geof Wood. Routledge: Taylor \& Francis.

BBC. 2013. "Bolivia's President Evo Morales Can Seek Third Term.” April 30, 2013

(https://www.bbc.com/news/world-latin-america-

22351190\#: :text=Bolivia's\%20Constitutional $\% 20$ Court $\% 20$ has $\% 20$ ruled,to $\% 20$ serve $\% 20$ two $\% 20$ conse cutive $\% 20$ terms.).

BBC. 2017. "Bolivia Court Allows President Evo Morales to Seek Fourth Term." November 29, 2017 (https://www.bbc.com/news/world-latin-america42161947\#: :text=Bolivia's\%20Constitutional\%20Court $\% 20$ has\%20allowed,proposal\%20to\%20change \%20the $\% 20$ constitution.).

Bermeo, Nancy. 2016. “On Democratic Backsliding.” Journal of Democracy 27(1): 5-19.

Bleck, Jaimie. 2012. "Countries at the Crossroads 2011: Mali." Freedom House. https://www.refworld.org/docid/4ecba6492f.html.

Bleck, Jaimie and Kristin Michelitch. 2015. "The 2012 Crisis in Mali: Ongoing Empirical State Failure.” African Affairs 114(457): 598-623. 
Bora, Birce. 2017. “Turkey’s Constitutional Reform: All You Need to Know”. Aljazeera. January 17, 2017 (https://www.aljazeera.com/indepth/features/2017/01/turkey-constitutional-reform170114085009105.html).

Cagaptay, Soner. 2010. "Turkey after the Constitutional Referendum: Implications for Washington.” The Washington Institute, Policy Watch 1705. Retrieved June 18, 2020

(https://www.washingtoninstitute.org/policy-analysis/view/turkey-after-the-constitutional-referendumimplications-for-washington).

Centellas, Miguel. 2013. "Bolivia's New Multicultural Constitution: The 2009 Constitution in Historical and Comparative Perspective." In Understanding Latin America's Multiculturalism and Autonomy Movements, eds. Michael S. Danielson, Todd Eisenstadt, Moisés J. B. Corres, and Carlos S. Polo, 88-110. New York: Oxford University Press.

Cheeseman, Nic and Marja Hinfelaar. 2009. "Parties, Platforms and Political Mobilization: The Zambian Presidential Election of 2008." African Affairs 109(434): 51-76.

Choudhury, Khadija Farhana. 2019. "Bangladesh's Media under Siege." The Diplomat. Retrieved May 22, 2020 (https://thediplomat.com/2019/03/bangladeshs-media-under-siege/).

Collyns, Dan and Jonathan Watts. 2016. "Bolivian referendum goes against Evo Morales as voters reject fourth term". The Guardian. Retrieved March 29, 2020

(https://www.theguardian.com/world/2016/feb/22/bolivia-evo-morales-president-national-referendumfourth-term).

Commonwealth Lawyers Association. 2019. "The Proposed 2019 Constitution Amendment Bill: A Threat to Zambia's Democracy?" Retrieved May 19, 2020 (https://www.commonwealthlawyers.com/africa/theproposed-2019-constitution-amendment-bill-a-threat-to-zambias-democracy/).

Commonwealth Legal Information Institute (CommonLII). 2004. "Constitution of the People's Republic of Bangladesh.” Retrieved February 18, 2020

(http://www.commonlii.org/bd/legis/const/2004/index.html).

“Constitution of the Republic of Turkey 1982." Retrieved January 12, 2020

(https://www.ilo.org/wcmsp5/groups/public/---ed protect/---protrav/---

ilo_aids/documents/legaldocument/wems_127495.pdf).

"Constitution of Zambia 1996." Retrieved March 26, 2020

(https://www.ilo.org/dyn/natlex/docs/ELECTRONIC/26620/90492/F735047973/ZMB26620.pdf).

"Constitution of Zambia 2016." Government of Zambia Act No. 2 of 2016. Retrieved July 2, 2020 (http://constitutionnet.org/sites/default/files/constitution-of-zambia-amendment-2016-act-no-2.pdf).

Cooley, Alexander. 2015. "Authoritarianism Goes Global: Countering Democratic Norms." Journal of Democracy 26(3): 49-63.

Corbell, Svante E. 2014. “Erdogan's Looming Downfall: Turkey at the Crossroads.” Middle East Quarterly 21(2).

Coskun, V. 2013. "Constitutional Amendments under the Justice and Development Party Rule." Insight Turkey 15(4): 95-113. 
Dagron, Alfonso G. 2012. "Media and Democracy in Bolivia." NACLA. Retrieved March 9, 2020 (https://nacla.org/article/media-and-democracy-bolivia).

Diwara, Sidi M. 2017. "Mali: Peace Process, Constitutional Reform, and an Uncertain Political Future." The Constitution Project, International IDEA (Institute for Democracy and Electoral Assistance). Retrieved June 1, 2020 (http://constitutionnet.org/news/mali-peace-process-constitutional-reform-anduncertain-political-future).

Dhaka Tribune. 2019. "Bangladesh Drops Four Notches in World Press Freedom Index." Retrieved April 30, 2020 (https://www.dhakatribune.com/media/2019/04/18/bangladesh-drops-four-notches-in-worldpress-freedom-index).

Earp, Madeline. 2012. "Bangladesh Backsliding on Press Freedom." Committee to Protect Journalists (CPJ). Retrieved June 13, 2020 (https://cpj.org/2012/06/bangladesh-backsliding-on-press-freedom/).

Electoral Institute for Sustainable Democracy in Africa (EISA). 2016. "Zambia 2016 Referendum Results". Johannesburg, South Africa. Retrieved July 29, 2020

(https://www.eisa.org.za/wep/zam2016referendum.htm).

Farthing, Linda. 2017. "Bolivia Says Goodbye to Term Limits.” NACLA. Retrieved March 1, 2020 (https://nacla.org/news/2017/12/20/bolivia-says-goodbye-term-limits).

Felter, Claire and Nathalie Bussemaker. 2020. "What to Know About the Crisis in Mali." Council on Foreign Relations. Retrieved August 12, 2020 (https://www.cfr.org/in-brief/what-know-about-crisismali).

Fish, M. Steven, Jason Wittenberg, and Laura Jakli. 2018. "A Decade of Democratic Decline and Stagnation.” In Democratization, ed. Christian W. Haerpfer. Oxford: Oxford University Press.

Foa, Roberto S. and Yascha Mounk. 2016. “The Democratic Disconnect.” Journal of Democracy 27(3): 5-17.

Freedom House. 2009. "Freedom in the World: Turkey." Washington, D.C.: USA. Retrieved May 5, 2020 (https://freedomhouse.org/sites/default/files/2020-02/Freedom in the World 2009 complete book.pdf).

Freedom House. 2009a. "Freedom in the World: Zambia." Washington, D.C.: USA. Retrieved May 8, 2020 (https://freedomhouse.org/sites/default/files/2020-

02/Freedom in the World 2009 complete book.pdf).

Freedom House. 2011. "Freedom in the World 2011: Zambia." Washington, D.C.: USA. Retrieved April 10, 2020 (https://freedomhouse.org/sites/default/files/2020-

02/Freedom in the World 2011 complete book.pdf).

Freedom House. 2011b. "Freedom in the World 2011: Turkey." Washington, D.C.: USA. Retrieved April 10, 2020 (https://freedomhouse.org/sites/default/files/2020-

02/Freedom in the World 2011 complete book.pdf).

Freedom House. 2013. "Freedom in the World: Bangladesh." Washington, D.C.: USA. Retrieved June 8, 2020 (https://freedomhouse.org/sites/default/files/2020-

02/Freedom in the World 2013 complete book.pdf). 
Freedom House. 2013a. "Freedom in the World: Ukraine." Washington, D.C.: USA. Retrieved June 8, 2020 (https://freedomhouse.org/sites/default/files/2020-

02/Freedom in the World 2013 complete book.pdf).

Freedom House. 2013b. "Freedom of the Press: Bolivia." Washington, D.C.: USA. Retrieved January 13, 2020 (https://www.refworld.org/docid/5220658f8.html).

Freedom House. 2013c. "Freedom in the World: Mali." Washington, D.C.: USA. Retrieved February 19, 2020 (https://freedomhouse.org/sites/default/files/2020-

02/Freedom_in the_World_2013_complete_book.pdf).

Freedom House. 2013d. "Freedom of the Press: Mali." Washington, D.C.: USA. Retrieved February 27, 2020 (https://www.refworld.org/docid/5187a20943.html).

Freedom House. 2013e. "Freedom in the World: Turkey." Washington, D.C.: USA. Retrieved March 11, 2020 (https://freedomhouse.org/sites/default/files/2020-

02/Freedom in the World 2013 complete book.pdf).

Freedom House. 2013f. "Democracy in Crisis: Corruption, Media, and Power in Turkey." Washington, D.C.: USA. Retrieved April 23, 2020 (https://freedomhouse.org/sites/default/files/2020-

02/SR_Corruption_Media Power_Turkey_PDF.pdf).

Freedom House. 2014. "Freedom in the World: Zambia." Washington, D.C.: USA. Retrieved June 10, 2020 (https://freedomhouse.org/sites/default/files/2020-

02/Freedom in the World 2014 complete book.pdf).

Freedom House. 2015. "Freedom in the World." Washington, D.C.: USA. Retrieved June 17, 2020 (https://freedomhouse.org/sites/default/files/2020-02/Freedom in the World 2015 complete book.pdf).

Freedom House. 2016. "Freedom of the Press: Mali." Washington, D.C.: USA. Retrieved April 19, 2020 (https://www.justice.gov/eoir/page/file/915851/download).

Freedom House. 2016. "Freedom in the World." Washington, D.C.: USA. Retrieved April 29, 2020 (https://freedomhouse.org/sites/default/files/2020-02/Freedom in the World 2016 complete book.pdf).

Freedom House. 2018. "Freedom in the World". Washington, D.C.: USA. Retrieved March 14, 2020 (https://freedomhouse.org/sites/default/files/2020-02/FreedomintheWorld2018COMPLETEBOOK.pdf).

Freedom House. 2020. "Freedom in the World 2020: A Leaderless Struggle for Democracy." Washington, D.C.: USA. Retrieved August 1, 2020 (https://freedomhouse.org/sites/default/files/202002/FIW_2020_REPORT_BOOKLET_Final.pdf).

Gandhi, Jennifer. 2018. "The Institutional Roots of Democratic Backsliding." The Journal of Politics 81(1): 11-16.

Hoffman, Max \& Werz, Michael. 2013. "Freedom of the Press and Expression in Turkey". Center for American Congress, 14 May 2013.

https://www.americanprogress.org/issues/security/reports/2013/05/14/63159/freedom-of-the-press-andexpression-in-turkey/ 
Human Rights Watch. 2018. "Bangladesh: Crackdown on Social Media.” Retrieved August 21, 2020 (https://www.hrw.org/news/2018/10/19/bangladesh-crackdown-social-media\#).

Human Rights Watch. 2017. “Turkey: President Bids for One-Man Rule.” Retrieved January 20, 2020 (https://www.hrw.org/news/2017/01/18/turkey-president-bids-one-man-rule\#).

Human Rights Watch. 2020. "Bangladesh: Online Surveillance and Control.” Retrieved July 17, 2020 (https://www.hrw.org/news/2020/01/09/bangladesh-online-surveillance-control\#).

International Bar Association. 2007. "Bolivia: IBA Calls on President Morales to Desist from Undermining the Rule of Law." Retrieved June 18, 2020

(http://www.ibanet.org/Article/Detail.aspx?ArticleUid=5DDE8323-44A8-47D2-88D6-E1C45658633).

International Institute of Strategic Studies (IISS). 2017. "Turkey Approves Constitutional Amendment". Retrieved March 9, 2020 (https://www.iiss.org/blogs/analysis/2017/04/turkey-constitutional-amendment).

Jones, Dorian. 2018. "Turkey's Ruling Party Extends Control Over Media." VOANEWS. Retrieved February 23, 2020 (https://www.voanews.com/europe/turkeys-ruling-party-extends-control-over-media).

Kabwe, Henry. 2009. "Press Freedom Slips in Zambia". Committee to Protect Journalists (CPJ). Retrieved January 24, 2020 (https://cpj.org/2009/08/press-freedom-slips-in-zambia/).

Khan, Addeba A. 2015. "The Politics of Constitutional Amendments in Bangladesh: The Case of the Non-political Care-taker Government.” International Review of Law 9: 1-16.

Kirisci, Kemal and Amanda Sloat. 2019. "The Rise and Fall of Liberal Democracy in Turkey: Implications for the West.” Brookings Institution. Retrieved December 23, 2019 (https://www.brookings.edu/research/the-rise-and-fall-of-liberal-democracy-in-turkey-implications-forthe-west/).

Kramer, David J. 2011. "Sounding the Alarm Round: Protecting Democracy in Ukraine." Freedom House. Retrieved November 21, 2020 (https://freedomhouse.org/sites/default/files/inline images/98.pdf).

Lansner, Thomas R. 2011. "Countries at the Crossroads 2011: Zambia." Freedom House. Retrieved February 7, 2020 (https://www.refworld.org/docid/4ecba6401a.html).

Lara, Tania. 2011. "Bolivia Approves Law to Increase State Control of Media, Permits Wiretapping". Knight Center for Journalism in the Americas, The University of Texas at Austin. Retrieved January 19, 2020 (https://knightcenter.utexas.edu/blog/bolivia-approves-law-increase-state-control-media-permitwiretapping).

Laws of Bangladesh. 2020. "The Constitution of the People's Republic of Bangladesh". Government of the People's Republic of Bangladesh, Legislative and Parliamentary Affairs Division. Retrieved August 11, 2020 (http://bdlaws.minlaw.gov.bd/act-367.html).

Levitsky, Steven and Daniel Ziblatt. 2018. How Democracies Die. New York: Penguin Random House.

Londono, Ernesto. 2019. "Bolivian Leader Evo Morales Steps Down”. The New York Times. Retrieved August 11, 2020 (https://www.nytimes.com/2019/11/10/world/americas/evo-morales-bolivia.html). 
Lührmann, Anna and Lindberg, Staffan I. 2019. "A Third Wave of Autocratization Is Here: What Is New About It?” Democratization 26(7): 1095-1113.

Lumina, Cephas. 2016. “Zambia's Constitutional Referendum: More Rights and Questionable Legitimacy?” The Constitute Project. Retrieved March 29, 2020 (http://constitutionnet.org/news/zambiasconstitutional-referendum-more-rights-questionable-legitimacy).

Lumina, Cephas. 2019. “Zambia's Proposed Constitutional Amendments: Sowing the Seeds of Crisis?" The Constitute Project. Retrieved March 29, 2020 (http://constitutionnet.org/news/zambias-proposedconstitutional-amendments-sowing-seeds-crisis).

Majumdar, Badiul Alam. 2013. "Legitimacy and Legality of $15^{\text {th }}$ Amendment." The Daily Star. Retrieved June 30, 2020 (https://www.thedailystar.net/news/legitimacy-and-legality-of-15th-amendment).

Migdalovitz, Carol. 2007. "Turkey's 2007 Elections: Crisis of Identity and Power." Congressional Research Service (CRS) Report for Congress. Retrieved June 16, 2020 (https://fas.org/sgp/crs/mideast/RL34039.pdf).

Martinez, Alejandro. 2014. "Bolivia Created Government-operated Media Network to Control Public Opinion, New Book Says". Knight Center for Journalism in the Americas, The University of Texas at Austin. Retrieved July 28, 2020 (https://knightcenter.utexas.edu/blog/00-15488-bolivian-governmentcreated-\%E2\%80\%9Cgovernment-operated $\%$ E2\%80\%9D-media-network-control-public-opinion).

Munalula, M. Margaret. 2016. "The 2016 Constitution of Zambia: Elusive Search for a People-driven Process." The Constitute Project. Retrieved July 27, 2020 (http://constitutionnet.org/news/2016constitution-zambia-elusive-search-people-driven-process).

National Assembly of Zambia. 2019. "The Constitution Amendment Bill, 2019." Retrieved April 21, 2020 (http://www.parliament.gov.zm/node/8067).

Odhikar. 2013. "Human Rights Report 2013: Odhikar Report on Bangladesh.” Dhaka, Bangladesh. Retrieved June 12, 2020 (http://odhikar.org/wp-content/uploads/2014/08/Annual-Human-Rights-Report2013-eng.pdf).

Oneko, Sella. 2019. “Zambia's Constitutional Debate: More Powers for the President?” $D W$. Retrieved November 30, 2019 (https://www.dw.com/en/zambias-constitutional-debate-more-powers-for-thepresident/a-51337992).

Political Database of the Americas. 2005. "Political Constitution of the Republic of Bolivia." Retrieved August 20, 2019 (https://pdba.georgetown.edu/Constitutions/Bolivia/consboliv2005.html\#parte2titulo2cap1).

Reuters. 2017. "Mali President postpones referendum on reforms". Retrieved March 29, 2020 (https://www.reuters.com/article/us-mali-politics/mali-president-postpones-referendum-on-reformsidUSKCN1AZ0CS).

Riaz, Ali. 2019. "Legislature as a Tool of the Hybrid Regime: Bangladesh Experience". Political Science \& Politics 52(2): 275-276.

Riaz, Al. 2013a. "Bangladesh in Turmoil: A Nation on the Brink?" Testimony before the Subcommittee on Asia and the Pacific Committee on Foreign Affairs United States House of Representatives. Retrieved 
April 17, 2020 (https://docs.house.gov/meetings/FA/FA05/20131120/101512/HHRG-113-FA05-WstateRiazA-20131120.pdf).

Riaz, Ali. 2013b. "Democracy in Bangladesh: A Report Card”. South Asia Journal 7.

Riaz, A. 2020. "A Pandemic of Persecution in Bangladesh". The Atlantic Council. Retrieved May 31, 2020 (https://www.atlanticcouncil.org/blogs/new-atlanticist/a-pandemic-of-persecution-inbangladesh/?fbclid=IwAR37pRSfQ etYAmdHEhoVeN5B96V DoTtK8yhbaf0czL6IS-1 bjcHqXHX8).

Romero, Simon. 2009. "Bolivians Ratify New Constitution". The New York Times. Retrieved June 21, 2020 (https://www.nytimes.com/2009/01/26/world/americas/26iht-26bolivia.19668052.html).

Sangare, Idrissa. 2017. "Thousands March against the Referendum, Extra Powers for Mali President." Reuters. Retrieved May 26, 2020 (https://www.reuters.com/article/us-mali-politics/thousands-marchagainst-referendum-extra-powers-for-mali-president-idUSKBN1A00LH).

Simutanyi, Neo. 2010. "The State of Zambian Democracy: Left Organizations and Their Role in Political Struggles". Centre for Policy Dialogue (CPD), Zambia. Retrieved July 15, 2020 (http://www.alnef.org.za/conf/2010/presentantions/zambia.pdf).

Simutanyi, Neo. 2013. "The Politics of Constitutional Reform in Zambia: From Executive Dominance to Public Participation." In Accountable Government in Africa: Perspectives from Public Law and Political Studies, eds Danwood Chirwa and Lia Nijzink. New York \& Paris: The United Nations University Press.

Simutanyi, Neo, Alastair Fraser, and Nalukui Milapo. 2015. "Background Paper: Politics and Interactive Media in Zambia". PiMA Working Paper 3, The University of Cambridge. Retrieved July 27, 2020 (https://www.repository.cam.ac.uk/bitstream/handle/1810/248622/PiMA\%20WP\%203\%20Zambia\%20B ackground\%20Paper.pdf?sequence=1).

South Asia Journal. 2012. “Journalism in Bangladesh: A Stricken Path.” Retrieved July 14, 2020 (http://southasiajournal.net/journalism-in-bangladesh-a-stricken-path/).

The Constitute Project. 2020. "Bolivia (Plurinational State of)'s Constitution of 2009. The Oxford University Press. Retrieved February 20, 2020

(https://www.constituteproject.org/constitution/Bolivia_2009.pdf).

The Constitute Project. 2020a. "Mali's Constitution of 1992." The Oxford University Press. Retrieved June 5, 2020 (https://www.constituteproject.org/constitution/Mali_1992.pdf?lang=en).

The Constitute Project. 2011. "Turkey's Constitution 2011.” The Oxford University Press. Retrieved August 6, 2020 (https://www.constituteproject.org/constitution/Turkey_2011).

The Daily Star. 2011. "Unelected People Must Not Come to Power Again”. Retrieved July 31, 2020 (https://www.thedailystar.net/news-detail-191989).

The Business Standard. 2020. "Freedom of Expression Declined in Bangladesh: Report." Retrieved June 2, 2020 (https://tbsnews.net/bangladesh/freedom-expression-declined-bangladesh-report).

The Guardian. 2014. "Bolivia Elects Evo Morales as President for Third Term." Retrieved June 1, 2020 (https://www.theguardian.com/world/2014/oct/13/bolivia-evo-morales--president-third-term). 
“The Constitution of Zambia [Amendment] Bill, 2019." Retrieved June 2, 2020

(http://www.parliament.gov.zm/sites/default/files/documents/bills/The $\% 20$ Constitution $\% 20$ of $\% 20$ Zambia $\% 20 \% 28$ Ameement $\% 29 \% 20$ Bill $\% 202019$.pdf).

Tolksdorf, Dominik. 2014. "The Constitutional Process in Ukraine: Issues in Play." The United States Institute of Peace. Retrieved July 27, 2020 (https://www.usip.org/publications/2014/05/constitutionalprocess-ukraine).

Trochev, Alexei. 2011. “A Constitution of Convenience in Ukraine.” JURIST. Retrieved Muly 15, 2020 (https://www.jurist.org/commentary/2011/01/jurist-guest-columnist-alexei-trochev/).

TRTWORLD. 2017. “Turkey's Constitutional Reform: A Review of Constitutional History, Current Parliamentary System, and Proposed Presidential System.” TRTWORLD Research Centre, NR 004. Retrieved June 22, 2020 (https://www.trtworld.com/referendum/images/key/research.pdf).

Varieties of Democracy (V-Dem). 2020. "Autocratization Surges - Resistance Grows: Democracy Report 2020." Gothenburg: Sweden: V-Dem Institute. Retrieved August 1, 2020 (https://www.V-

dem.net/media/filer public/f0/5d/f05d46d8-626f-4b20-8e4e-

53d4b134bfcb/democracy report 2020 low.pdf).

Walsh, Frank M. 2010. "The Legal Death of the Latin American Democracy: Bolivarian Populism's Model for Centralizing Power, Eliminating Political Opposition, and Undermining the Rule of Law." Law and Business Review of the Americas 16(2), 241-258.

Wing, Susanna D. 2015. "Hands Off My Constitution: Constitutional Reform and the Workings of Democracy in Mali." Journal of Modern African Studies 53(3): 451-475.

Yegen, Oya. 2017. "Constitutional Changes under the AKP Government in Turkey". BIJ DE BUREN. Retrieved July 31, 2020

(https://heinonline.org/HOL/Page?handle=hein.journals/tvcrl2017\&div=10\&g sent=1\&casa token=\&col lection=journals).

Zissis, Carin. 2006. "Bolivia's Nationalization of Oil and Gas." Council on Foreign Relations. Retrieved July 22, 2020 (http://www.cfr.org/publication/10682/). 